\title{
A Geological Model Of The Kao Kimberlites, Lesotho, Based On The Petrography Of Limited Samples
}

\author{
E. Michael W. Skinner \\ Geology Dept., Rhodes University, Grahamstown, South Africa.
}

\section{Introduction}

The Kao kimberlites, consisting of a Main pipe complex of $\sim 20$ ha and a Satellite pipe of $\sim 3$ ha, are situated in Lesotho at an altitude of $2500 \mathrm{~m}$ abmsl $\sim 25 \mathrm{~km}$ to the SW and $\sim 500 \mathrm{~m}$ below the Letseng la Terae kimberlites. The Kao Main pipe has previously been recognized as a single pipe separated into six main geological varieties (Rolfe, 1973). But in this study, it is indicated that the Main pipe is a complex of at least five separate bodies. These include; the largest body in the west, consisting of the Fragmental kimberlite pipe into which is intruded a large irregular body referred to as the Gritty kimberlite plus other smaller internal dykes, a smaller pipe in the south-east known as the Quarry kimberlite, and at least 3 separate intrusive kimberlites situated in between the Fragmental and the Quarry pipes, referred to here as the Lower Quarry Suite. The shapes and sizes of these bodies are different from those represented by Rolfe (1973), however, the true relationships between these bodies are still uncertain due mainly to sample limitations.

\section{Petrography}

\section{Framental kimberlite}

The Fragmental kimberlite forms the largest body within the Main pipe. It has sharp contacts with Karoo basalt at slope angles of about $82^{\circ}$ as indicated by drilling. Three kimberlite types were registered by Rolfe (1973), as the Fragmental, the Transitional and the Fine-Fragmental, however, although differences are apparent in thin section these differences do not fit with the boundaries as indicated by Rolfe, 1973 and in this study all three varieties are included under one banner, namely the Fragmental kimberlite. All specimens are macroscopically similar. They are all massive, poorly sorted, fragmental rocks, characterized by abundant (19 to 45 vol. \%) angular, Karoo basalt xenoliths and abundant, anhedral, commonly fresh olivine macrocrysts set in a finer matrix. Also present to the naked eye are variable proportions of kimberlite magmaclasts ranging in size up to 50 $\mathrm{mm}$. These vary from common, more abundant, irregular, angular clasts to rare, spherical clasts.

Microscopically, different specimens can vary significantly. All specimens contain kimberlite magmaclasts (from abundant to rare). In most cases these have irregular, angular boundaries suggesting that these magmaclasts are broken. The magmaclasts range from clasts consisting of one grain of olivine (from $<0.1 \mathrm{~mm}$ to $>5 \mathrm{~mm}$ ) to many grains of olivine with generally incomplete selvages or attachments of finer-grained groundmass. Many of the olivine macrocrysts are unusually fresh. In some specimens the groundmass to the magmaclasts is free of microlitic diopside and consists of abundant, very fine, granular, colourless, serpentinized monticellite, plus fine phlogopite laths, opaque spinels (up to $0.09 \mathrm{~mm}$ ) and perovskite (up to $0.16 \mathrm{~mm}$ ) set in a base of serpentine (Fig. 1). But in others the groundmass to the magmaclasts has similar original mineralogy but also contains pervasive microlitic diopside particularly as a replacement of the serpentinized monticellite. In some specimens many olivine grains occur individually without attachments of finer groundmass (i.e. they occur outside of magmaclasts). In all specimens, larger sized components (including xenoliths, olivines and magmaclasts) are coated by very thin rims of

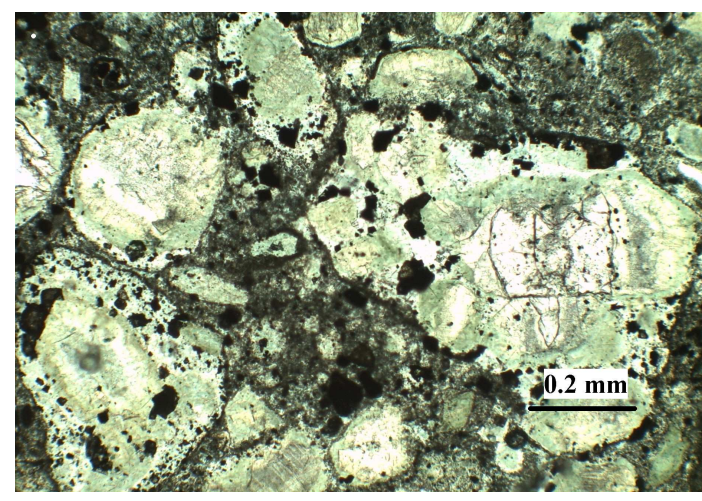

Fig. 1. Fragmental kimberlite characterized by irregularly bounded magmaclasts set in an inter-fragmental matrix of mainly microlitic diopside. 
concentrated microlitic diopside. Microlitic diopside is also uniformly distributed in the interfragmental matrix together with a colourless, very fine-grained, very low birefringent mineral thought to be 'serpentine'. The ratio of 'serpentine' to microlitic diopside varies from one specimen to the next. Small xenoliths of basalt are very rare within the irregular magmaclasts but they do occur. Blocks of country rock basalt (up to $40 \mathrm{~m}$ across) occur within the Fragmental kimberlite close to the pipe contacts. These blocks probably represent "floating reef" inclusions.

\section{Gritty kimberlite}

The Gritty kimberlite is a highly irregular body, as indicated by drilling, and is intrusive into the core of the Fragmental kimberlite. The most striking feature of this rock is the presence of numerous spherical to elliptical, globular structures of kimberlite (Fig.2). These range in size from < $0.1 \mathrm{~mm}$ to $>18 \mathrm{~mm}$. In most cases, these structures contain kernels of country rock xenoliths and/or olivine macrocrysts surrounded by variably sized mantles of finer-grained kimberlite. This consists mainly of small olivine phenocrysts set in a much finer-grained groundmass. This groundmass consists of relicts of very fine-grained, granular, serpentinized monticellite, very fine phlogopite and evenly-distributed, euhedral, opaque spinels $(<0,07$ $\mathrm{mm}$ ) and perovskite (up to $0.2 \mathrm{~mm}$ ) all set in a base of 'serpentine'. In all cases much of the fine groundmass, particularly the serpentinized monticellite, is replaced by microlitic diopside. All olivine grains are contained within the globules but many xenoliths occur outside of globules. In most specimens, relicts of fresh olivine occur. Olivine

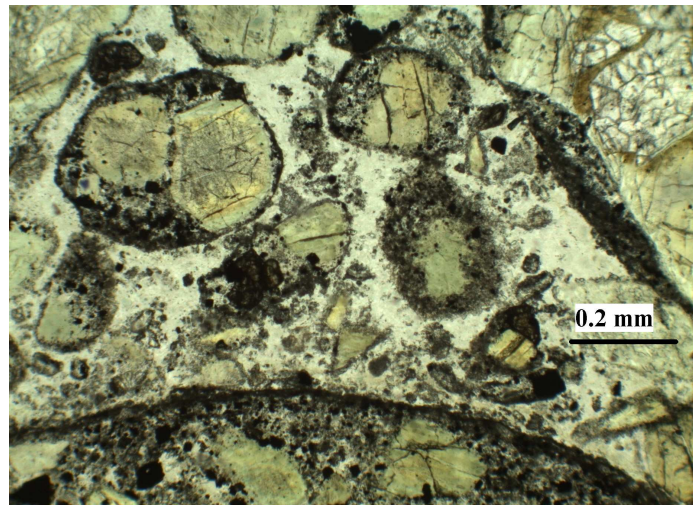

Fig. 2. Gritty kimberlite characterised by globular segregations set in an inter-globular matrix mainly of 'serpentine' and lesser calcite. grains range in size from $7 \mathrm{~mm}$ to $<0.1 \mathrm{~mm}$. In several globules, small spherical segregations (up to $0,2 \mathrm{~mm}$ across) or vesicles of 'serpentine' exist. All larger sized components are coated by very thin rims of concentrated microlitic diopside. Very rare tiny grains of this material can also be seen within the inter-globular matrix of 'serpentine' and minor calcite.

\section{Other lesser intrusive bodies associated with the Fragmental kimberlite}

Besides the Gritty kimberlite, there are several other bodies associated with the Fragmental kimberlite. These include a dyke-like kimberlite close to the western contact of the pipe and aphanitic, micro-breccia dykes that transect the basalt - kimberlite contact on the western and southern edges of the Fragmental kimberlite. The dyke-like kimberlite on the west side is $\sim 1 \mathrm{~m}$ wide at surface and up to $17 \mathrm{~m}$ wide at depth. It is a coherent, macroscopic kimberlite consisting of rare country rock xenoliths plus abundant olivine macrocrysts and phenocrysts in a finer groundmass. This groundmass consists of abundant very fine phlogopite, vague serpentinized grains after possible monticellite, rare laths of highly altered possible melilite, prominent grains of perovskite (up to $0.18 \mathrm{~mm}$ ), smaller euhedral opaque spinels (up to $0.07 \mathrm{~mm}$ ) and abundant irregular segregations of serpentine in some cases containing highly irregular corroded rhombs of calcite and laths of apatite. Much of the groundmass away from the serpentine-calcite-apatite segregations is partly replaced by hydrogrossular.

\section{Lower Quarry Suite kimberlites}

At least three separate types of coherent kimberlites (Lower Quarry Suite A, B and C) occur within an area denoted by Rolfe, 1973 as the Lower Quarry kimberlite located within country rock basalt in between the Fragmental kimberlite (in the NW) and the Quarry kimberlite (in the SE).

The Lower Quarry Suite A kimberlite is a coherent, segregationary, macrocrystic kimberlite containing abundant olivine macrocrysts and smaller phenocrysts plus highly altered country rock xenoliths (< 15 vol. \%) and irregular segregations of serpentine. Olivine grains, in many cases consisting of glomero-porphyritic aggregates of more than one grain, are surrounded by finergrained groundmass minerals. These include a 
'necklace' of fine opaque minerals (up to 0.07 $\mathrm{mm}$ ), relatively coarse-grained perovskite (up to $0.2 \mathrm{~mm}$ ) and other finer-grained minerals including phlogopite and vague serpentinized monticellite. Much of this fine-grained groundmass is effectively masked by seconadary hydrogrossular. The base to the rock consists of abundant, small, irregular segregations filled with mainly serpentine and pectolite in places.

The Lower Quarry Suite B kimberlite is a coherent, globular segregationary, macrocrystic kimberlite breccia, containing abundant olivine macrocrysts and carbonated country rock xenoliths (> 15 vol. \%). Microscopically the rock has a fine globular segregationary texture, wherein all altered olivine grains have very thin coats (generally $<0.1$ $\mathrm{mm}$ ) of fine-grained material, including mainly microlitic diopside, phlogopite plus opaque spinels and perovskite (up to $0.08 \mathrm{~mm}$ ). In all cases the diopside has partly replaced the margins of the olivine grains of which it surrounds. The interglobular matrix consists of serpentine and calcite.

The Lower Quarry Suite C kimberlites are xenolith-free, coherent, macrocrystic kimberlites. They consist of abundant olivine macrocrysts and phenocrysts set in a finer-grained groundmass of phlogopite, accessory apatite, relatively abundant opaque spinels (up to $0.11 \mathrm{~mm}$ ) and perovskite in a base of calcite and serpentine.

\section{Quarry kimberlite}

The Quarry kimberlite occurs as a separate, small pipe to the south-east of the Fragmental kimberlite. All the specimens analysed are petrographically similar. Macroscopically they are fragmental, poorly sorted, massive rocks consisting of abundant relatively fresh country rocks of mainly Karoo basalt (up to 37 vol. \%) and abundant clay mineralized olivine macrocrysts set in a finer matrix. In thin section this matrix is seen to consist of abundant small, pelletal magmaclasts (generally $<0,5 \mathrm{~mm}$ ) set in a very fine-grained, interfragmental matrix of microlitic diopside and 'serpentine'. The pelletal magmaclasts consist of one or more olivine grains surrounded by thin selvages of, very fine-grained, granular, serpentinized monticellite, phlogopite laths, perovskite (up to $0.1 \mathrm{~mm}$ ) and lesser opaque

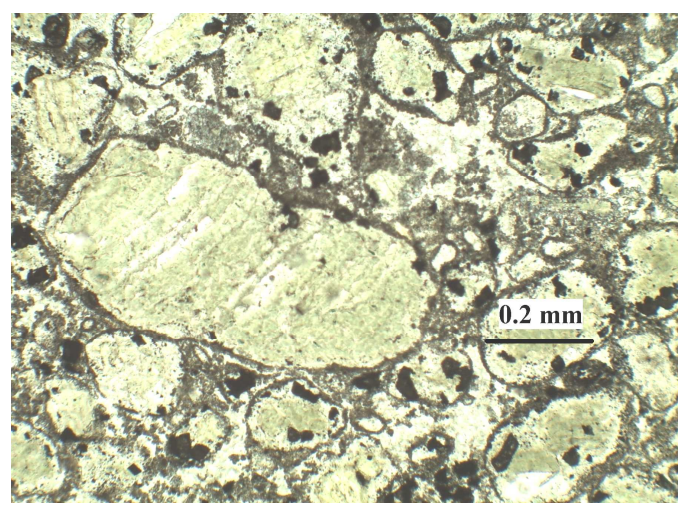

Fig. 3. Quarry kimberlite characterised by small pelletal magmaclasts set in an inter-clast matrix of microlitic diopside and 'serpentine'.

spinels $(<0.05 \mathrm{~mm})$ in a base of serpentine. Note these magmaclasts are free of microlitic diopside. Although rare olivine macrocrysts are contained within larger-sized, spherical magmaclasts (up to 7 $\mathrm{mm}$ ), most olivine macrocrysts are broken. These have highly irregular margins, and are not contained within magmaclasts. Basalt xenoliths are also not contained within magmaclasts. As is the case in the Fragmental and Gritty kimberlites, larger sized components, including country rock xenoliths, 'free' olivine macrocrysts and juvenile magmaclasts, are all surrounded by very thin rims of microlitic diopside.

\section{The Kao Satellite pipe}

A single specimen from the centre of the pipe is a coherent, macroscopic kimberlite breccia. It consists of altered xenoliths ( 24 vol. \%), fresh to serpentinized olivine macrocrysts and smaller phenocrysts plus rare macrocrysts of phlogopite set in a fine-grained matrix. This matrix consists mostly of abundant, evenly distributed, microlitic diopside crystals (up to 0,07mm), evenly distributed, euhedral, opaque spinels and perovskite (up to $0,1 \mathrm{~mm}$ ), rare small phlogopite crystals and a base of calcite and serpentine. There is a vague textural indication of the possible earlier existence of abundant groundmass serpentinized monticellite that has been largely replaced by the microlitic diopside. The latter mineral has also partly replaced the margins of serpentinized olivine grains.

\section{Discussion}

\section{Fragmental kimberlite}


The Fragmental kimberlite was classified by Clement (1973) as a "non-tuffaceous, porphyritic breccia" but is without doubt a massive, volcaniclastic rock, similar to Class 1, tuffisitic kimberlites (Mitchell et al., 2009) or Kimberleytype pyroclastic kimberlite (Scott Smith et al., 2011) but it exhibits significant differences. These, include the presence of common fresh olivine, the presence of angular broken magmaclasts (instead of typical complete pelletal magmaclasts) and different specimens exhibit varied petrography. The freshness of olivine could relate to a relative scarcity of available juvenile water. The angularity of most magmaclasts suggests that they were explosively fragmented possibly from original solidified globular structures (re. Gritty kimberlite). The inhomogeneous petrography of these specimens suggests that gas-solid fluidisation was probably not involved in the formation of these rocks. This might also relate to a relative scarcity of juvenile water as a driving force for fluidisation. In spite of the differences this kimberlite appears to have been deposited within the conduit similar to typical tuffisitic kimberlites.

\section{Gritty kimberlite}

Clement (1973) classified this rock as a "tuffaceous" kimberlite and interpreted the globular segregations as "pelletal lapilli". However, the Gritty kimberlite is a highly irregular body that is clearly intrusive into the Fragmental kimberlite. It does not have a pipe shape with $+/-82^{\circ}$ sloped contacts, typical of Class 1 pyroclastic kimberlites. Also petrographically it shows no evidence of having been fragmented by explosion. Although it does contain country rock xenoliths, these are generally $<15$ vol \% and, like xenoliths present in other coherent kimberlites at Kao, they are more highly altered than xenoliths present in the Kao pyroclastic kimberlites. Other features that are atypical of Class 1 pyroclastic kimberlites include the presence of fresh olivine, the scarcity of microlitic diopside in the inter-globular matrix and the presence of minor primary calcite together with 'serpentine'. In this study the characteristic gritty or pelletal structures are here referred to as globular segregations rather than magmaclasts as the rock is not considered to be clastic. Although microlitic diopside is more or less absent from the interfragmental matrix it is abundant as an autometasomatic mineral in the globulular segregations and also occurs as thin concentrated rims around the outer margins of all larger-sized components as is the case in the Fragmental and Quarry kimberlites. The intrusive style and the petrographic evidence indicates that this kimberlite did not form by explosive eruption. It is not a welded tuff as has been suggested for similar rocks at Venetia, Brown et al., 2008, but instead formed within a changing hypabyssal environment dominated by rapid crystallization and nucleation of the solid groundmass phases plus exsolution and segregation of volatile phases. In this study the Gritty kimberlite is classified as an intrusive, coherent, "diatreme-type" (Skinner \& Marsh, 2004) transitional kimberlite.

\section{Lower Quarry Suite kimberlites}

The Lower Quarry Suite kimberlites form a complex of small kimberlite plugs and dykes that cut the country rock basalt and probably predate all other kimberlites at Kao. The Lower Quarry Suite A kimberlite is classified as a coherent, segregationary, xenolith-rich, macrocrystic, altered phlogopite-monticellite kimberlite. The Lower Quarry Suite B kimberlite is classified as coherent, transitional, "hypabyssal-type" (Skinner \& Marsh, 2004), globular segregationary, macrocrystic, pyroxenitized, calcite-bearing phlogopite kimberlite breccia. The Lower Quarry Suite C kimberlites are classified as coherent, hypabyssal macrocrystic, calcite-phlogopite kimberlites. As in other transitional kimberlites the globular segregationary texture and crystallization of microlitic diopside is thought to have developed within a magmatic environment as a consequence of second boiling. Note that in this kimberlite the transitional texture and mineralogy is not as advanced as in the case of the Gritty kimberlite. There is no question that the Lower Quarry Suite B kimberlite is intrusive. Like the Gritty kimberlite, this kimberlite has not exploded nor being emplaced by pyroclastic processes and there no evidence of welding as is suggested in similar kimberlites at Venetia (Brown et al., 2008). These kimberlites are interpreted as subvolcanic embryonic bodies (re. Clement \& Reid, 1989).

\section{Quarry kimberlite}

The Quarry kimberlite is classified as a xenolith-rich, tuffisitic kimberlite or Kimberleytype pyroclastic kimberlite (Scott Smith et al., 2011) similar to the Wesselton, tuffisitic 
kimberlites described by Mitchell et al., 2009. But it differs from Wesselton in that pelletal magmaclasts are free of microlitic diopside (present at Wesselton) and contain abundant pseudomorphs after monticellite (absent at Wesselton). It is noted that most of the larger sized olivine grains are broken whereas the magmaclasts are not broken as is the case in the Fragmental kimberlite. These magmaclasts are much smaller than the magmaclasts in the Fragmental kimberlite and the globular segregations in the Gritty kimberlite. They are considered to represent classic juvenile lapilli that are completely solidified after the initial explosion and fluidisation processes that formed these rocks.

\section{The Kao Satellite}

This kimberlite is classified as a coherent, transitional, "hypabyssal-type", macrocrystic, calcite-bearing, pyroxenetized, kimberlite breccia.

\section{Conclusions}

In consideration of the absence of in-situ crater-facies at Letseng and at Kao and the difference in altitude between Kao and Letseng, it is concluded that Kao has been eroded by at least $1 \mathrm{~km}$ since emplacement.

The main pipe at Kao consists of a complex of at least seven separate bodies. These include, in probable order of emplacement: At least three separate, coherent kimberlites that are intrusive into basalt (Lower Quarry Suite) including one that is a transitional, hypabyssal-type. These bodies could represent an embryonic stage in the formation of the kimberlite complex. A later unique pyroclastic kimberlite (Fragmental) is emplaced within the conduit of a steeply sided pipe in country rock basalt. A large, irregular, transitional, "diatremetype" kimberlite (Gritty) is intrusive into the Fragmental kimberlite. Also intrusive into the Fragmental kimberlite, on the west side of the pipe, is a dyke-like body of coherent kimberlite. Lastly one typical Kimberley-type, pyroclastic kimberlite (Quarry) forms a smaller, steeply sided pipe emplaced into the basalt in the south-east side of the complex. Also present, close to the margins of the Fragmental kimberlite, as narrow, late stage cross-cutting dykes, are at least two types of aphanitic micro-breccias interpreted as tuffisites. One sample of the Kao Satellite pipe is interpreted as a coherent, transitional, "hypabyssal-type" kimberlite.

The Kao kimberlites are interpreted as Class 1 kimberlites (Skinner \& Marsh, 2004) that form by the emplacement of early embryonic pipes and dykes Clement \& Reid (1989) development of coherent transitional kimberlites (Skinner \& Marsh, 2004 and Skinner, 2008) and later development of explosively erupted pyroclastic kimberlites. Petrographic differences between all the kimberlites at Kao are all thought to relate to differences in the development of the kimberlites relating to second boiling processes, differences in volatile content and the extent of $\mathrm{CO}_{2}$ degassing. The coherent uniform to segregationary kimberlites in most cases, contain primary calcite in their groundmass and are relatively poorly degassed. The transitional kimberlites contain less calcite and are moderately degassed whereas the pyroclastic kimberlites are free of calcite and are extensively degassed with respect to $\mathrm{CO}_{2}$.

\section{References}

Brown, R.J., Buse, B., Sparks, R.S.J., Field, M, 2008. On welding of pyroclasts from very low-viscosity magmas: Examples from kimberlite volcanoes. Jour. Geol., 116, 354-374.

Clement, C.R., 1973. Kimberlites from the Kao pipe, Lesotho. In Lesotho Kimberlites, Ed. P.H.Nixon, 110-121. Lesotho Natl. Dev. Corp., Maseru.

Clement, C.R., Reid, A.M., 1989. The origin of kimberlite pipes:an interpretation based on the synthesis of geological features displayed by South African occurrences. Proc. 9IKC: Geological Soc. Australia special publication, 14, 632-646.

Mitchell, R.H., Skinner, E.M.W. Scott Smith, B.H., 2009. Tuffisitic kimberlites from the Wesselton Mine, South Africa: Mineralogical characteristics relevant to their formation. Lithos 112S, 452-464.

Rolfe, D.G., 1973. The Geology of the Kao kimberlite pipes. In Lesotho Kimberlites, Ed. P.H.Nixon, 101106. Lesotho Natl. Dev. Corp., Maseru.

Scott Smith, B.H., Nowicki, T.E., Russell, J.K., Webb, K.J., Mitchell, R.H., Hetman, C.M., Harder, M., Skinner, E.M.W., Robey, J.V., 2011. Kimberlite Terminology and classification : A rationalization. Short Abstracts, $10^{\text {th }}$ Int. Kimb. Conf.

Skinner, E.M.W., Marsh, J.S., 2004. Distinct kimberlite pipe classes with contrasting eruption processes. Lithos 76. 183-200.

Skinner, E.M.W., 2008. The emplacement of Class 1 kimberlites. J. of Volc. \& Geothermal Research. 40-48. 